\title{
Wokół pedagogiki krytycznej (retrospekcja i projekcja na tle problemów i doświadczeń w pedagogice polskiej)
}

\section{Wstęp ${ }^{1}$}

Chciałbym poczynić kilka uwag metodologicznych i meta-narracyjnych, dotyczących strategii w traktowaniu tzw. pedagogiki krytycznej, czy "radykalnej”, jako nie tylko przedmiotu dociekań, ale także perspektywy rozumienia w pedagogice polskiej naszego bycia w świecie społecznym, akademickim, w sferze publicznej i edukacji, zarówno przez pryzmat zmian z ostatnich dwudziestu pięciu lat, stanu na dziś, jak i pod kątem kierunku zmian pożądanych na przyszłość. Kieruję się tu swoim doświadczeniem zajmowania się tym nurtem czy typem refleksji od początku lat 80. XX wieku, a także niedawną próbą ogarnięcia całości recepcji pedagogiki krytycznej w wersji związanej z publikowanymi w Polsce przekładami prac Henry'ego A. Girouxa, bądź prac jego współautorstwa i z moimi analiza$\mathrm{mi}^{2}$. Miło mi, że mogę podkreślić, że $\mathrm{w}$ próbie bilansu recepcji pedagogiki krytycznej udział biorą $\mathrm{w}$ tym tomie, $\mathrm{w}$ trybie przedmowy, posłowia i aneksu główni protagoniści tej recepcji w osobach profesorów: Zbigniewa Kwiecińskiego, Tomasza Szkudlarka, Zbyszko Melosika oraz Bogusława Śliwerskiego. Wszystkie te głosy z pewnością warto uwzględnić, jako dające świadectwo tego, czym stało się w Polsce zjawisko pedagogiki krytycznej czy radykalnej. Pragnę także zwrócić uwagę na fakt, że w książce tej opublikowałem obszerny rozdział pt. O stanie recepcji amerykańskiej pedagogiki radykalnej w Polsce. Próba świadectwa osobistego i refleksji o "doświadczeniu pokoleniowym”, do którego odsyłam po szczegóły, rozwinięcia i dokumentację tez, które mogę tu jedynie sygnalizować.

Chcę w moim wystąpieniu zrobić trzy główne odsłony. Najpierw pozwolę sobie na pewne zastrzeżenia oraz na kilka uwag niemal anegdotycznych, pragnąc przywołać znamienne okoliczności osadzające kwestie samej pedagogiki krytycz-

1 Podstawą tego eseju jest tekst mojego wystąpienia plenarnego na otwarcie konferencji „Pedagogika krytyczna dziś. Pytania o teorię i praktykę", Gdańsk, 28 maja 2012 roku w Instytucie Pedagogiki UG. Zasadniczy trzon tego wystąpienia pozostaje tu niezmieniony.

2 H.A. Giroux, L. Witkowski, Edukacja i sfera publiczna. Idee i doświadczenia pedagogiki radykalnej, Oficyna Wydawnicza „Impuls", Kraków 2010. 
nej w realnych odniesieniach do postaw i losów jej twórców. Nastąpi potem retrospekcja dotycząca tego, co się wydarzyło z nami samymi, gdy zaczęliśmy $\mathrm{w}$ naszym pokoleniu jeszcze młodych doktorów w gronie seminaryjnym Zbigniewa Kwiecińskiego w IRWiR PAN w Toruniu zdawać sobie sprawę i rozumieć konsekwencje płynące dla nas z faktu, że jest coś takiego jak fenomen pedagogiczny Girouxa i nurtu krytycznego. W trójkącie środowisk i ich liderów: T. Szkudlarek i Gdańsk, Z. Melosik i Poznań oraz Z. Kwieciński i Toruń, z moim skromnym udziałem, powstały w kolejnych latach impulsy, o których sam Zygmunt Bauman pisał już wprost jako o ważnych dla niego samego i dla historii nauk pedagogicznych, widząc w nich przejawy „szkoły poznańsko-toruńsko-gdańskiej”3. A są to przejawy postawy krytycznej w pedagogice wyrosłej na naszym przewartościowaniu jednocześnie marksizmu, postmodernizmu, szkoły frankfurckiej i poststrukturalizmu francuskiego.

Wreszcie, w trzeciej odsłonie, musi paść kluczowe pytanie: co to znaczy dzisiaj uprawiać pedagogikę krytyczną w Polsce i dlaczego znaczyć to może, a nawet musi, coś innego niż w USA? I na koniec nie unikniemy kwestii - na czym opierać najlepszy możliwy krytycyzm w pedagogice, jeśli da się go zaprojektować czy choćby postulować z jakimiś konkretami? Amerykańska pedagogika krytyczna pokazała, że przeszła całą masę inspiracji, które dla nas pozostały ciągle zadaniem do podjęcia. Tymczasem my nawet nie mamy za sobą świadomości dotyczącej dokonań naszej rodzimej tradycji i jej krytyczności ani tego, jak się ona wpisuje w ewolucję pedagogiki krytycznej na Zachodzie. Przykład niech stanowi fakt, że $\mathrm{w}$ polskiej pedagogice jeszcze międzywojennej mamy wiele akcentów uczulających na wagę zjawisk oporu w interakcjach edukacyjnych (wychowawczych), podczas gdy przejście $\mathrm{w}$ analizach krytycznych do paradygmatu oporu - po strategii rozpoznawania mechanizmów reprodukcji przez edukację różnych aspektów nierówności - jest na ogół traktowane jako wpisane w późną fazę ewolucji postaw w pedagogice zachodniej, wiązaną z okresem lat 70 .

\section{Zastrzeżenia i motywacje oraz ukierunkowania programowe krytycyzmu}

Muszę się zastrzec, że mam świadomość, że nie jestem tu bezstronny, rzecz jasna, jako uczestnik pewnego procesu, jaki się zaczął i nie sądzę, żeby się już zakończył, ani nawet nie jestem pewien, czy jeszcze intensywnie trwa, choć wydaje mi się nadal ważny i potrzebny. Krytyczna refleksja meta-pedagogiczna jawi się tu tym bardziej jako niezbędna, że mam przekonanie o narastającym kryzysie intelektualnym $w$ naszym środowisku akademickim, o czym długo by mówić; niech tu wystarczy, że sporo już o tym pisałem, jak łatwo się przekonać. Na dodatek, sporym utrudnieniem dla mnie w podejmowaniu perspektywy zdystansowanej

\footnotetext{
3 Ponowoczesność jako źródło cierpień, Wydawnictwo Sic!, Warszawa 2000.
} 
relacji jest to, że nie tyle pociąga mnie samo analizowanie pedagogiki krytycznej, ile raczej jej uprawianie, a tu w narracji muszę tymczasem trochę zmienić postawę. Genetycznie widziana, pedagogika ta wymaga wskazania na jej źródłowo ważne tradycje krytyczne, po czym niezbędne jest badawczo podejmowanie ich tropów, jak to zrobiłem z Bachtinem, Bourdieu i częściowo z Lacanem za Giroux i McLarenem, oraz z Eriksonem i Kohlbergiem za Habermasem. Funkcjonalnie z kolei trzeba wskazać na nowe obszary, zadania i specyfikę podejścia tej pedagogiki, wpisane zwłaszcza w zdolność rozpoznawania zjawisk wcześniej niewidocznych, jak przemoc symboliczna, czy szerzej na przejawy ukrytego programu i rytualizację pozoru, a także wskazać zdolność problematyzowania strategii gdzie indziej uchodzących za oczywiste czy wystarczająco lepsze od innych. W tym, dla przykładu - mimo rozmaitych przewag (neo)liberalizmu nad przezwyciężanym bagażem doświadczeń związanych z totalitaryzmem rozmaitych odmian, łącznie z generującą postawy homo sovieticus - trzeba umieć rozpoznać zjawiska wymagające krytyki $\mathrm{w}$ świecie coraz bardziej posttotalitarnym, ale też uwikłanym w sprzeczności i pułapki neoliberalizmu i globalizację, i to w sposoby nie dające się łatwo nazwać ani rozsupłać z ich splotów i inercji czy uwodzącego naiwnych kamuflażu.

Najtrudniej jest krytycznie budować dyskurs wobec świata, który zaczyna mieć objawy braku podatności na obalenia i wpisany jest w niego, z jednej strony, mechanizm zasłaniania się proceduralnością (gdzie demokracja sama staje się zakładnikiem procedur), oraz globalności, gdzie różnica zaczyna tracić na znaczeniu i wartości, z drugiej. A wszystko za przyzwoleniem jednostek coraz mniej refleksyjnych i coraz bardziej wyzbywających się podmiotowości obywatelskiej, czy zdolności do brania odpowiedzialności za los własny i społeczny w dłuższej perspektywie procesów budowania demokracji i wrastania w kulturę inną niż doraźnie nagłośniona medialnie. Nieprzypadkowo Giroux uczula na „nowy autorytaryzm neoliberalizmu", krytykowany aż w kategoriach terroru. I to ostatnie słowo też musi być krytycznie widziane, gdyż - jak w jednej z wypowiedzi zauważył to przenikliwie Tomasz Szkudlarek - „neoliberalizm jest słabo inwazyjny", a nawet uwodzący. Oddziałuje środkami miękkimi, dając iluzoryczne ostatecznie poczucie komfortu i braku uzależnienia. Trzeba umieć rozpoznawać środki tego nowego sposobu oddziaływania, aby znaleźć możliwości przeciwstawiania się ich ukrytym wpływom. Obok strategii politycznej poprawności warto wyróżnić presję kultury organizacji i interakcji, zdominowanej modelem proceduralności. Porządek gwarantowany już nie przez hierarchię czy decyzyjność w punkcie wyjścia, ale poprzez procedury, które się stawia w miejsce odpowiedzialności, zdolności do troski, etycznej wrażliwości. Pojawia się więc świat, w którym dominuje przemoc politycznej poprawności (ostentacyjna uprzejmość fałszuje ukryte podłości), uwikłanie uzależniające w perwersyjną i perfidną socjalizację oraz troska o dominację konwencjonalności w sensie Habermasa, w postaci procedur i proceduralności działań, stającej się nową przestrzenią rytualizacji pozoru, przez co jeden z włodarzy miasta powiedział mi kiedyś, że „,konkursy są dla 
tych, którzy mają je wygrać". Także w edukacji coraz częściej wysiłki skupione są na wytwarzaniu świata papierowych zgodności, upragnionych przez każdego biurokratę, zamiast realnej troski o autentyczną życiodajność, jeśli ta nie jest mierzalna, modularnie poszatkowana i definiowalna w deklaratywnych pożytkach kompetencyjnych po krótkiej sekwencji impulsów.

Coraz częściej jesteśmy ofiarami mechanizmów nie tylko ukrytych, ale także przewrotnie posługujących się ukradzioną tożsamością, zawłaszczoną tradycją, językiem afirmującym prawo (a w istocie uzurpatorskie roszczenie) do bycia poza krytyką, jako obiekt naturalizowany, czy kontynuujący świetlane etosy. Interakcje społeczne i organizacje jako przestrzeń roszczen, ukrytych, przezroczystych, milczących - to perspektywa, której włączenie do analiz pedagogicznych jest konieczne, mimo że dokonuje się z oporami; tu Habermas od dawna powinien być elementarzem, a nie jest. Co więcej okazuje się, że owe uzurpacje działają w konwencji orwellizacji nowomowy, odwracającej sensy, a dokładniej, nakładającej etykiety na sytuacje i nowe twory, wręcz nowotwory zaprzeczające skojarzeniom z tymi etykietami wiązanym.

W ramach moich własnych ujęć krytyczności wzrasta waga ciągle u nas lekceważonej, acz obecnej już w tradycji międzywojennej, czujności pedagogicznej wobec obosieczności środków działania wychowawczego oraz złożoności dwubiegunowej podstawowych zjawisk, które redukowane do jednoznaczności stają się zwykle reduktami jednostronnymi, gubiącymi konieczność widzenia procesów i praktyk z drugiej strony. Musimy sobie umieć poradzić z wymogiem uwzględnienia krytyczności w postaci jej paradoksalnej siły chronienia od przesady, przerostów czy skrajności z jednej strony, a od braku, deficytu i nieadekwatności, $z$ drugiej. Krytycyzm nie da się już prosto wiązać z postulatem zmiany, gdyż krytycyzm musi umieć uderzyć także w same zmiany, ich strategie i sposoby realizacji, nakazuje dostrzegać ich przejawy szkodliwe, chore, czasem oszalałe i ślepe albo naiwne, czy też wpisane $\mathrm{w}$ charakterystyki typowe dla tzw. orwellizacji świata, gdzie jego opis jest dokładnie w duchu "nowomowy” (newspeak) zaprzeczeniem jego sensu i narzucaniem perspektywy zmuszającej do ślepoty i uczestnictwa w podtrzymywaniu świata na to nie zasługującego. Krytycyzm wpisuje w postawę poznawczą refleksyjność, która rozpoznaje także przewrotność efektów ciążących nad intencjami, gdzie refleks - jako odbicie zwrotne skutków w postaci wypaczonego echa - bywa nierozpoznany przy braku narzędzi do adekwatnego pojęcia, czyli rozumiejącego przetworzenia wyjściowej postawy. Krytycyzm musi umieć żywić się jakimiś impulsami także ze sfery zjawisk, wobec których potrafi wezwać do buntu, alarmując, a nie tylko diagnozując i zgłaszając niepokój. Dla budowy krytycyzmu czy jego rozpoznawania ważne szczególnie jest pytanie o to, czym jest on motywowany i jakim ukierunkowaniem (niekoniecznie projektem, czy tym bardziej utopią) żyje, na rzecz czego chce działać, za jaką cenę i z jakim dopuszczaniem do głosu różnicy w obrębie sporów o jego (tj. krytycyzmu) konstytuowanie.

W polskich realiach szczególnie ważne i trudne jest wpisanie krytycyzmu w dyskurs zajmujący się obecnością religii w szkole, stosunkiem do ciała i do nie- 
pełnosprawności oraz tym, jak przeciwdziałać skutkom programów reform, których nie da się zatrzymać, zahamować, czy odwrócić. Jak pokazałem już gdzie indziej, mamy przynajmniej cztery możliwe strategie pedagogiczne ukryte za odmiennymi stosunkami do tradycji, innymi wizjami wolności i wyzwalania duchowości ludzkiej, odmiennymi zapotrzebowaniami na zmianę i wreszcie innymi ideałami miejsca, co łącznie wymaga zupełnie odmiennych wyobrażeń o możliwości dialogu, spotkania z kulturą, o mechanizmach komunikacyjnych i ich racjonalności. Zupełnie inna skala krytycyzmu dochodzi do głosu, gdy potrafimy dostrzec potrzebę "racjonalności transwersalnej” (której wagę dla pedagogiki społecznej odkryła i wdraża Ewa Marynowicz-Hetka) czy - gdy pamiętając o triadzie rozwojowej Habermasa-Kohlberga czy jej antycypacji u Sergiusza Hessena w znanej sekwencji: anomii-heteronomii-autonomii - potrafimy krytycznie analizować obosieczność proceduralności (poziomu konwencjonalnego w terminologii Habermasa), co najbardziej chyba spektakularnie przybliżył Leszek Kołakowski $\mathrm{w}$ analizie obosieczności kodeksowego regulowania odpowiedzialności zawodowej we wzorcowym dla krytycznej czujności eseju Etyka bez kodeksu (ze słynnego tomu Kultura i fetysze).

Dla pedagogiki szczególnie ważne wydaje mi się nieustanne naruszanie jej wyobrażenia o socjalizacji (ze względu na jej stereotypizacje i redukcje złożoności do wymagań lokalnych) i uwypuklanie przemocy obecnej w oddziaływaniu uzyskującym "dobrowolną uległość”, aż po rzekomo pożyteczną i pożądaną „nienaruszalność" autorytetu i afirmację uwiedzenia czy fascynacji. Pedagogika krytyczna uczy rozumieć, że niebezpieczeństwa i realnie groźne zjawiska nie polegają głównie na agresji, ostentacji czy skwapliwej ofensywności. Bywają one słabo inwazyjne, a nawet uwodzące, i siłę oddziaływania uzyskują pozornym brakiem zainteresowania uzależnieniem. Wiemy też, że niezbędne jest śledzenie zjawiska odwróconej skuteczności (efektu odwrotnego od zamierzonego nie pomimo wysiłków w przeciwną stronę, ale dzięki nim), czy wręcz perwersyjności i perfidii zacierania po sobie śladów, aby szczytowe przejawy dominacji i czynienia ofiarą były dla jednostki im poddanej niedostępne refleksyjnie, a tym bardziej dla generowania gestów oporu, trudnych, jeśli nie już całkowicie niemożliwych w uwikłaniu w "syndrom ofiary" z jednej strony, a narcystycznego skupienia na zaspokajaniu potrzeb i zachcianek konsumenta na rynku dóbr, stosującego którąś $\mathrm{z}$ postaw będących zaprzeczeniem zaangażowania pielgrzyma $\mathrm{w}$ kulturze, co znakomicie opisał Bauman, uczulając jak wiemy między innymi na roszczenia turysty czy włóczęgi, dla których oferta edukacyjna czy wysiłek rozwojowy same w sobie nie mają wartości. A odsłoniłem już osobno za Baumanem diagnozę „,końca kultury uczenia się", jako dodatkowego wyzwania dla edukacji, przesłoniętego przez fikcję sloganu "społeczeństwa wiedzy"4. 2009.

L. Witkowski, Ku integralności edukacji i humanistyki II, Wydawnictwo Adam Marszałek, Torun 


\section{O pułapce etykietowania $\mathrm{w}$ nauce na przykładzie krytycyzmu}

Mówić o pedagogice krytycznej i pisać o pedagogice krytycznej można sensownie jedynie wówczas, moim zdaniem, gdy się ją jednocześnie uprawia, kultywuje, stosuje do własnej postawy dla dobra całej pedagogiki, a nie jakiejś kolejnej wygodnej dla profesorów czy adeptów szuflady, z której można wyjmować teksty na awans lub tolerowane teksty o jakimś egzotycznym tworze. Gdy zarazem jest się czujnym wobec pułapek i zagrożeń. Jestem przeciwny tworzeniu getta z kręgu zajmującego się tą JUŻ tradycją myślową w pedagogice zachodniej, mającą swój kanon, warianty, postaci formatu światowego i ewolucję. Nie chodzi też o to, aby widzieć tu jednorodne zjawisko, ani tym bardziej zasługujące na bezkrytycyzm i jednostronne afirmacje. Jak mało która etykieta, sama formuła „krytyczności” obejmuje zadanie meta-narracyjne, odniesienia do własnych roszczeń. Nie darmo Marek Siemek uczulał na dwoiste, nieredukowalne napięcie w historii filozofii między biegunem krytyki i biegunem systemu, gdzie łatwo o bezkrytycznie traktowany system albo o krytykę pozbawioną systemowego oparcia jako uprawomocnienia jej roszczeń.

Etykietka afirmująca „krytyczność” nie daje placetu na słuszność, nie może być zwolnieniem z czujności i odpowiedzialności, choć sami sobie często zastawiamy tu pułapki i zgłaszamy uzurpatorskie aspiracje, albo przynajmniej kuszące obietnice. Tak chociażby jak reklamowana w telewizji zupa "smaczna” nie może być smaczna mocą nazwy na torebce, tak psychologia zwana "humanistyczną" nie ma żadnych racji do wyższości, a tym bardziej jedyności standardu reprezentowania takiego bycia tylko z powodu tej nazwy, bywając zarazem naiwną, płytką czy wyrzuconą poza obręb złożoności zjawisk, wymagającej aż znajomości psychoanalizy, w jej wersji dalekiej od ortodoksji redukcjonistycznej.

Takich przykładów z uzurpacjami, albo nieszczęściem etykiet i ich obietnic, jest cała masa. Znamienny jest przykład związany z tzw. pedagogiką socjalistyczną, której wtórowali w większości niestety wielcy naszej tradycji pedagogicznej po wojnie. Tam, gdzie pedagogika ta ma rację i zachowuje aktualność, nie ma nic wspólnego z socjalizmem, gdyż ma wartość poza tą etykietą i jej odniesieniem, pod wieloma względami ułomnym. Nie jesteśmy więc zakładnikami etykiety uznając jakieś jej elementy za pozytywne. Tam z kolei, gdzie ta tradycja pedagogiczna obrosła rozmaitymi usiłowaniami, jest błędna, nawet etykieta socjalizmu nie pomaga, a - co więcej - staje się wręcz przeszkodą dla wysiłku odróżniania pozytywów od nieporozumień. Podobnie marksizm, jako filozofia „postępowa” z nazwy, nie umiał kryć braku postępowości w wielu swoich rozbieżnych wcieleniach, podobnie jak kościół dumny z określenia katholikos, czyli powszechny, wcale z mocy nazwy taki nie jest i staje przed wyzwaniem ekumenizmu. Przypomnijmy, że krytyka Lutra u zarania reformacji nie tyle postulowała 
jakiś nowy kościól, ile walczyła o to, aby kościół ówczesny nie tylko nominalnie dochowywał wierności swojej misji chrześcijańskiej, a nie skazywał na kojarzenia "papieża” jako „anty-Chrysta”. Wiemy zatem, że za etykietami często kryją się potężne roszczenia, a nawet uzurpacje, maskujące interesy związane z dążeniem do panowania określonej konstelacji sił. W historii filozofii krytyczną etykietę kojarzono najpierw głównie z tradycją kantowską, a potem z teorią krytyczną rodem z Frankfurtu nad Menem, w sporze z „racjonalizmem krytycznym” Karla Poppera, zatem krytycyzm niejedno ma imię, ale dobrze by było, aby o niego się troszczyć i nad nim zastanawiać.

Podobnie, choć pedagogika krytyczna ma swoje naturalne odnogi i odniesienia do tradycji marksizmu, to krzywdę by się jej robiło wpisując ją w całości i wyłącznie w tę tradycję. Zarazem byłoby absolutnym nieporozumieniem, gdyby niechęć wobec np. Engelsa czy Lenina miała stanowić alibi dla potępiania w czambuł postawy Antonia Gramsciego, czy wersji czytania tej tradycji w wersji np. frankfurckiej, nie mówiąc już o powrocie do refleksji etycznej „młodego Marksa”.

Dyskusja o pedagogice krytycznej musi sama być krytyczna. I to szerzej niż w odniesieniu do jakiejś zamkniętej całości. Nie chciałbym, abyśmy powielali tu błędy, a przynajmniej nawyki z podejściem do innych etykiet, jak: pedagogika alternatywna, pedagogika postmodernistyczna, pedagogika emancypacyjna. Pedagogika krytyczna chce być pedagogiką tout court, jako taką, a nie jakimś marginesem czy egzotycznym wariantem, dumnym ze swojej odrębności i wspaniałomyślnie uznającym prawo do równoprawnego funkcjonowania nurtów nieświadomych swojej ułomności, a nawet szkodliwości dla demokracji, dla postaw obywatelskich i dla jakości podmiotowego funkcjonowania człowieka w świecie kultury. Jest to w szczególności okazja do refleksji nad stanem całej pedagogiki w Polsce i jej części, jak pedagogika ogólna, pedagogika społeczna, pedagogika porównawcza. I projektowania zadań dla każdej oraz rozpoznawania ich mielizn czy zapóźnień. Zwłaszcza, gdy bywają całkowicie nieuświadamiane w typowej postawie pełnej dobrego samopoczucia.

Zamknąć tę część rozważań chcę prowokacyjną tezą. Jeśli pedagogika jest na serio - to jest krytyczna. Oczywiście to dopiero otwiera dramatyczne zadanie, jakie przed nami staje. Bo miary krytycyzmu niełatwo się dobić, jak i nie ma jednego tu ukierunkowania czy zamkniętej listy tematów do podjęcia. Mimo rozmaitych wyjściowych wzorców. I mimo zarazem sugestii, że nie ma jednej obowiązującej wersji pedagogiki krytycznej ani jednego jej ukierunkowania. Dodam zarazem jeszcze tytułem doprecyzowania, świadom dodatkowej komplikacji na wstępie, pewne zastrzeżenie do sygnalizowanych tu pułapek i sporów terminologicznych, które nie muszą być traktowane jako błahe. Otóż wyznam, iż ja sam wolę zdecydowanie termin: pedagogika radykalna. Raz, że łatwiej się bać tego terminu, bo radykalizm się źle kojarzy, choć ma etymologię związaną z korzeniami, z sięganiem korzeni zjawisk jako warunkiem następnie „wykorzeniania” z jednej strony, a troski o zakorzenienie np. w kulturze jako pamięci symbolicznej z drugiej. Rodzi to naturalnie czujność intelektualną i etyczną, jako pierwszy warunek krytycyz- 
mu sięgającego głęboko. Dwa, że trzeba się dobrze zastanowić nad tym, co i jak radykalizować (sam dawno już postulowałem radykalizację semantyczną pedagogiki). Trzy, że w związku z tym jest to termin bardziej teoretycznie wymagający ufundowania niż krytyczny, bo każdy chce być krytyczny, a nie zastanawia się nad tym, jak być krytycznym wobec ... samej krytyki. Chęć czy determinacja bycia radykalnym wymaga znacznie poważniejszego strategicznie uzasadnienia, wnikliwości i czujności. Co więcej, muszę się tylko odwołać do własnej już rozwijanej tezy o potrzebie „radykalizacji semantycznej” różnych kategorii w dyskursie pedagogicznym, także przy jego ambicjach akademickich, choćby po to, aby dało sie pogłębić kojarzenie rozmaitych kategorii, jako niosących rozmaite pułapki czy choćby zróżnicowanie semantyczne, gdzie sensowne użycie jakiegoś terminu wymaga zerwania z potocznymi skojarzeniami na jego temat. Kluczowym przykładem jest dla mnie wskazanie na napięcie między funkcją socjalizacji jako wiru redukcji kulturowej danego miejsca a edukacji jako wyrywania z tego wiru w trybie przekraczającym lokalne i doraźne oczekiwania i dominacje.

\section{Przyczynek do opisu recepcji pedagogiki krytycznej w Polsce}

Jeśli się nie mylę, to pierwszy trop dotyczący pedagogiki krytycznej odkryty w Polsce datuje się na początek lat 80., gdy na fali przebudzenia solidarnościowego napisałem list do Giroux z prośbą o przesłanie książki, której trop gdzieś znalazłem w literaturze, o wymownym i obiecującym tytule: Theory and resistance in education. Książka ta szybko stała się naszym wyjściowym źródłem otwarcia intelektualnego, zachęcając do pójścia tropami dotąd nawet u nas nie odkrytymi. Nieprzypadkowo jej partie były tłumaczone w kolejnych numerach Nieobecnych dyskursów, redagowanych przez Z. Kwiecińskiego w serii wychodzącej na UMK. Była to książka kluczowa dla dalszego rozwoju naszej świadomości metodologicznej, która uświadomiła nam nie tylko to, że jest gdzieś inna pedagogika, już dawno (lata 80.) krytycznie mająca przyswojoną tradycję frankfurcką i poprawiająca własny krytycyzm wobec realiów kapitalizmu przejściem od paradygmatu reprodukcji do paradygmatu oporu i to jeszcze krytycznie, a nie sentymentalnie afirmowanego.

Okazało się nie tylko, że jest gdzieś INNA pedagogika w stosunku do dominującej u nas, ale że pedagogika w ogóle może być, jest, a nawet być powinna INNA. Cała pedagogika powinna być inna. Że jej inspiracje mogą, a nawet muszą być inne, głębiej zrośnięte ze stanem filozofii, socjologii, nawet literaturoznawstwa i psychoanalizy. To jest główna dla mnie lekcja, która legła u podstaw kierunku dalszych poszukiwań i lektur, także naszej tradycji. Że kontakt z marksizmem nie musi być powieleniem dominacji wyznań nawet naszych czołowych koryfeuszy, ale może dostarczać narzędzi krytyki. Inne uprawianie pedagogiki przez T. Szkudlarka czy przeze mnie, przy wszystkich różnicach między nami 
wzięło się chyba z takiego odkrycia, mojego z czytania, a znakomitego gdańskiego pedagoga także z pobytu w Stanach u Giroux, gdy byliśmy jeszcze "piękni i młodzi" w latach 80 .

Wraz z nowymi lekturami odkryłem sobie w amerykańskiej pedagogice krytycznej trop rosyjskiej semiotyki Bachtina, co zaowocowało książką profesorską ${ }^{5}$ czy uznaniem wagi psychoanalizy francuskiej Jacquesa Lacana dla pedagogiki, co dało przeprowadzenie przeze mnie aż trzech doktoratów z psychoanalizy w pedagogice i filozofii. Odkryłem także dla siebie, że Pierre Bourdieu to wielki humanista, znakomicie zakorzeniony w historii filozofii (patrz Medytacje pascaliańskie), a nie "tylko" socjolog interesujący dla samych socjologów i dla prowadzących wąskie badania. Okazało się, że wszyscy oni dają pedagogice nowy język, krytyczny i zradykalizowany semantycznie, który nam się wcześniej nie śnił, a nagle zaczął występować z oczywistością, jako coś koniecznego i już przyswojonego przez pedagogikę na świecie.

Szybko też okazało się, jak bardzo wizja emancypacji jest zakorzeniona w przykładzie latynoamerykańskim Paolo Freirego, którego jednak w naszych oglądach zdarza się kojarzyć z jakąś inną wizją pedagogiki, oklejonej etykietą pedagogiki wyzwolenia. Odkryliśmy, że trzeba umieć zadawać sobie poważne, trudne i krytyczne pytanie, jakiej psychologii pedagogika potrzebuje i dlaczego? I dlaczego ta uczona nagminnie przez akademicką psychologię jest często za słaba. I dlaczego to musi być także psychoanaliza w wersji Lacana. Pedagodzy amerykańscy pokazywali dwadzieścia lat temu, że Lacan jest konieczny w pedagogice, podczas gdy my z rzadka nadal rozumiemy, że jest choćby tylko możliwy i wart przyglądania się dla zmiany sposobów patrzenia i rozumienia. Odsłonięcie wagi kategorii braku, jako niekoniecznie wiązanego z deficytem, a wpisanego $\mathrm{w}$ porządek pragnienia $\mathrm{z}$ jednej strony, a zarazem docenienie zdolności rozpoznawania braku jako podstawy działań, to tylko jeden z tropów, które wymagają wnikliwych studiów i włączenia w myślenie pedagogiczne.

Ale zarazem podkreślam, że błędem byłoby początek pedagogiki krytycznej kojarzyć w Polsce z naszym odkryciem Giroux i krytycznej socjologii edukacji z Applem. Żeby nie zaczynać dopiero od lat 80 . XX wieku, warto się nieco cofnąć. Przytoczmy znamienne zdanie z Mysłakowskiego z roku 1967 jako motto dla niektórych naszych aktualnych rozterek wobec normatywnych uzurpacji ministerialnych wpisanych w wizje i rozwiązania włączone w program reformy szkolnictwa wyższego. Mamy tu uczulenie na konieczność widzenia dwoistości zakresów wykształcenia, pod groźbą inaczej postawy samobójczej wobec kultury.

„Zapewne, motocykla nie zbudujemy za pomocą prawd zawartych np. w Księdze Hioba, ale i do życia nie staniemy się dojrzalsi przez znajomość mechaniki i umiejętności spawania". 2000,

L. Witkowski, Uniwersalizm pogranicza, Wydawnictwo Adam Marszałek, Torun 1991, II wyd. 
W skromnym tomiku niemal felietonów Mysłakowskiego pt. Zatracone ścieżki, zagubione ślady (1967) jest wpisana duża dawka dramaturgii, zarazem uczulająca na to, że pedagogika krytyczna musi być ... dramatyczna, nie może nie widzieć dramatu, a nawet tragedii, a tym bardziej rytualizacji pozorów. Chcę też dodać, że zaskakuje, gdy się Mysłakowskiego czyta, jak mocno afirmuje obecność wymiaru oporu w relacjach edukacyjnych, podczas gdy czytaliśmy, że paradygmat oporu nastąpił dopiero po trzech krytycznych odsłonach paradygmatu reprodukcji w sferze edukacji. Tytuł zbioru esejów też jest znamienny dla pedagogiki krytycznej: zatracone ścieżki, zagubione ślady, chcę tym nawiązać do idei z lat 80. promocji $\mathrm{w}$ polskiej pedagogice 'nieobecnych dyskursów'. Jednym $\mathrm{z}$ nich była pedagogika krytyczna. Czy przypadkiem z naszej winy nadal nie jest nieobecnym dyskursem i za jaką cenę?

Trzeba zatem krytycznie pytać: czy umiemy podejść do własnej tradycji z odsłanianiem w niej akcentów, jakie gdzie indziej przebijały się nawet później, ale się przebiły znacznie dobitniej? Czy ją krytycznie przyswajamy? A krytycznie oznacza nie tylko zaprzeczenie bezkrytyczności, ale i zaprzeczenie powierzchowności, brakowi silnych inspiracji, zdolności do odsłonięcia tropów, którymi warto dalej pójść. Które zobowiązują, które stają się narzędziem nie tylko obnażania, ale wręcz alarmistycznym wezwaniem do uruchamiania zmiany postaw. Krytycyzm musi być wpisany w formułę zaangażowania w znaczące kwestie społeczne, rozpoznawane jako przełomowe historycznie, jak to doskonale odczuwało pokolenie pedagogów polskich urodzonych $\mathrm{w}$ latach 80. XIX wieku, następnie $\mathrm{z}$ oddaniem rozwijających refleksję pedagogiczną $\mathrm{w}$ trosce o wspieranie powstania oświaty w państwie polskim odzyskującym niepodległość w 1918 roku po latach nieistnienia.

Zauważmy też na marginesie, że pod względem wyczulenia i otwarcia na psychoanalizę pedagogika przedwojenna w Polsce, zajmująca się choćby tylko najpierw głównie Adlerem i problemami z kompleksem niższości (także u nauczycieli jako przeszkodą w działaniu wychowawczym), była bardziej krytyczna i zaawansowana w przejmowaniu impulsów z nowej wówczas humanistyki niż nasza obecna. Nastąpił tu tymczasem regres kompetencyjny i zanik styków dyskursywnych, mozolnie dopiero odzyskiwanych w kolejnych studiach monograficznych (np. doktoraty z Lacana dla pedagogiki). Ja odkryłem u nich wagę szkoły frankfurckiej, a samodzielne lektury Habermasa odsłoniły wagę tropu teorii cyklu życia Eriksona i triady Kohlberga jako podbudowy wizji procesów rozwojowych, do dziś nie zastosowanych w całości w pedagogice. $W$ tym nurcie poszedłem, inaczej niż Giroux i McLaren, tropem teorii działania komunikacyjnego i jej odniesień u Habermasa. Wszystko to pozwala zobaczyć ograniczenia rozmaitych tropów dominujących $w$ naszych obiegowych skojarzeniach, jak związanych z afirmacją psychologii humanistycznej, czy hermeneutyki traktowanej w opozycji do myślenia krytycznego. Tymczasem wystarczy zauważyć, że w świetle podejścia Habermasa jest jasne, że ważna rozwojowo i edukacyjnie emancypacja nie da się zredukować do perspektywy hermeneutycznej i wymaga dopełnień uw- 
zględniających jej zakresy wpisane $w$ inne typy działań niż zorientowanych na (po)rozumienie. Wystarczy skojarzyć typy racjonalności i interesy poznawcze. Słabość recepcji pedagogiki krytycznej w Polsce ma wiele wspólnego ze słabością recepcji tradycji krytycznej w zakresie tradycji frankfurckiej, na co nie ma już alibi cenzuralnego po ponad 25 latach prób pokazywania tej tradycji i jej przekładów.

Po pierwszych rozmowach z prof. Kwiecińskim, który wówczas dostał zaproszenie do zostania dziekanem nowo powstającego wydziału na UAM, dyskutowaliśmy formułę przejęcia doświadczeń z Miami University na Florydzie, aby to była jednostka o nazwie Wydział Studiów Edukacyjnych (ewentualnie także kulturowych). Zaskakuje mnie, że to do dziś zupełnie osamotniony przypadek nazwania Wydziału w oderwaniu od dyscypliny, której nazwa gdzie indziej nawet niespecjalnie jest znana i uznana. Nie umiemy nawet korzystać z krytycznych doświadczeń innych.

Ważnym pożytkiem z odkrycia pedagogiki krytycznej była wyprawa studyjna prof. Tomasza Szkudlarka (jeszcze jako młodego adiunkta) do Stanów, jego znakomite przygotowanie, publikacje, w tym w USA, wcześniej wizyta Girouxa z McLarenem w Polsce, dokładniej w Toruniu na UMK, w Warszawie w IBE i w Poznaniu na UAM. To wszystko otworzyło drogę do przesilenia formacyjnego w Polsce, niosąc nowe impulsy pokoleniowe. Prawdopodobnie nie powtórzył się już potem taki skok pokoleniowy, który jednocześnie wygenerował i wypromował czołówkę pokoleniową aktywnych postaci nurtu krytycznego w pedagogice, w osobach przynajmniej: T. Szkudlarka, Z. Melosika, B. Śliwerskiego, R. Kwaśnicy i mojej skromnej osoby. Nie jest nadal jasne, czy to tylko epizod biograficzny nas dotyczący, czy coś, co istotnie zmieni psujący się klimat intelektualny w środowisku akademickiej pedagogiki w Polsce, na uniemożliwiający głębsze przejmowanie się postulatem krytycznej troski o edukację.

\section{Dwie czy trzy anegdoty na okoliczność świadectwa}

Warto moim zdaniem zwrócić uwagę na dokonany przez Girouxa wybór okładki dla naszej wspólnej książki Edukacja i sfera publiczna z motywem postaci Króla Ubu z Alfreda Jarry'ego, do tematu edukacja i sfera publiczna wprost genialnego, wykonanym przez litewskiego pochodzenia grafika zamieszkałego w Polsce, mającego renomę międzynarodową, Stasysa Eidgrigeviciusa. Postać zamaskowanego, uśmiechniętego przyjemniaczka, zarazem zgłaszającego rozmaite roszczenia (do władzy, do wyższości, do powagi, do życzliwości), miała symbolizować trudności w demaskowaniu ukrytych wymiarów komunikacji w przestrzeni edukacji. Jednym z moich najlepiej przyjętych wykładów był ten, gdy pokazując studentom grafikę Króla Ubu z okładki naszej książki z Giroux wyjaśniałem im, dlaczego doskonale pasuje do patologii przestrzeni publicznej i edukacji. Zamaskowani tak bywają i studenci, i profesorowie, zdominowani udawaniem, pozorem zaangażowania, uprzejmością, a nie otwartą agresją. Uśmiech i uwznioślenie 
postawą i przebraniem maskuje pustkę, stanowić może przejaw wytrwałej rytualizacji pozoru i jałowości uczestnictwa $\mathrm{w}$ procesie tylko $\mathrm{w}$ dalekim sensie, zbieżnym z troską o rozwój i pogłębienie kapitału symbolicznego. Zauważmy na marginesie, że są trzy typy zamaskowania (i wynikające stąd trzy strategie demaskacji). Inaczej trzeba postępować, gdy (a) maska jest ukrywana, z roszczeniem do tego, że jej nie ma, (b) maska jest traktowana jako przyrodzona, zatem nie podlega negocjacji jej zmiana czy zdjęcie, (c) maska jest bezwstydnie obnoszona jako taka z ostentacją uzurpacji z nią związanych (np. nic mi nie zrobicie, bo mam władzę).

Wspomnę tu także, w trybie nieco anegdotycznym, opór Girouxa wobec mojej propozycji umieszczenia w książce jego wspólnych z McLarenem tekstów, mimo że wydawali wspólne książki w latach 90., promując np. ideę granicy i pogranicza dla pedagogiki oraz wagę polityczności studiów kulturowych. Teraz uważał, że to zupełnie inne światy się zrobiły, gdyż McLaren stał się bardziej rewolucyjny w sensie klasyki marksistowskiej, znany zwłaszcza w Ameryce Łacińskiej w duchu lewicowym, z identyfikacją z Leninem i Che Guevarą. Giroux, po Miami i po uniwersytecie znanym jako Penstate (od Pensylwanii), wykłada obecnie w McMasters University w Hamilton w Kanadzie, a McLaren po UCLA wyemigrował do Nowej Zelandii do Aukland (pozostając profesorem obu uczelni). Zarazem w Meksyku otworzył Instytut McLarena Pedagogiki Krytycznej ze sztandarowym wezwaniem: „Uczyć dla lepszego świata”. Giroux zdominował swoje teksty analizami krytycznymi stanu kapitalizmu i mechanizmów dominujących w USA, wprowadzając $\mathrm{w}$ ostatnich latach dramatyczną terminologię: uniwersytet $w$ łańcuchach, Ameryka na krawędzi, terror neoliberalizmu. Został ostatnio zgłoszony do Nagrody Pulitzera w Kanadzie wraz z dwunastoma innymi intelektualistami. Giorux mniej ostatnio jeździ po świecie. McLaren za to podbija świat $\mathrm{w}$ miejscach zgłaszających zapotrzebowanie na lewicowe zaangażowanie polityczne i obywatelskie, uruchomił i nagłośnił instytucjonalne działania antykapitalistyczne $w$ ofensywie ideologicznej w duchu radykalnej lewicowości latynoamerykańskiej. Kiedy poprosiłem o przedmowę do polskiej edycji Schooling as ritual performance, McLaren przysłał tekst, w którym kluczową tezą jest to, że to CIA doprowadziła do wyboru Karola Wojtyły na Papieża JP II. Choć zarazem autor dał mi prawo do retuszu, z którego nie skorzystałem. Tekst został opublikowany tymczasem bez retuszu w tomie mi dedykowanym ${ }^{6}$. Da się to połączyć z faktem, że na swojej stronie internetowej na jej czołówce McLaren umieścił obraz Lenina, a szereg tekstów jest w duchu Che Guevary, przez co z jawną retoryką rewolucyjną amerykański radykał jest znany zwłaszcza w krajach latynoamerykańskich.

Wskazuję na te nieco anegdotyczne informacje z powodu dość zasadniczego i to na serio. Okazuje się bowiem, że nie ma jednego wzorca postawy politycznej w pedagogice krytycznej, co jest jej dużym potencjałem, wymagającym intelek-

6 Por. Ku integralności edukacji i humanistyki. Księga jubileuszowa dla Lecha Witkowskiego, pod red. Z. Kwiecińskiego, M. Jaworskiej-Witkowskiej, Wydawnictwo Adam Marszałek, Toruń 2009. 
tualnego mierzenia się ze światem neoliberalizmu i w obliczu fiaska mrzonek o socjalizmie państwowym po dramacie socjalizmu narodowego. Marksizm także może być obosieczny w postawie krytycznej, tyle ułatwiający, co przeszkadzający. I ta wspomniana już obosieczność etykiet, nie wyłączając pedagogiki krytycznej, jest tu ważną dla mnie tezą. Generalnie uważam, że etykiety (nawet dyscyplin) są zbyt redukcyjne, zbyt narzucają stereotyp skojarzeń, zbyt zamykają, zbyt zwalniają z poczucia obowiązku sięgnięcia, bo nasza etykietka jest inna. Bo nie chodzi o samą pedagogikę ani jej interes. Może to jest tym bardziej niezbędny i aktualny kierunek wpisania się w oczekiwania 'rynku'. Pamiętam, jako pouczającą, uwagę McLarena, że nie wystarczy mieć w głowie poukładane, ale trzeba być wiarygodnym dla odbiorcy, krótkie włosy z krawatem niszczą szansę na porozumienie ze studentami college' u w USA zanim otworzy się usta. Wypada podkreślić w naszych kontekstach, że interes pedagogiki czy środowisk pedagogicznych nie wszędzie jest tożsamy z interesem edukacji i kultury pedagogicznej. Mamy środowiska reprezentujące w swojej części przynajmniej antyświat akademicki, pilnując swoich interesów (układów, przeciętności, stabilności). Nie darmo tak trudno walczyć o interes edukacji, gdy dominuje interes nauczycieli, reprezentowany np. przez związek zawodowy nauczycielstwa.

Większość naszych wydziałów to wydziały pedagogiki czy pedagogiczne, jeśli nie ukryte wśród historyków na Wydziale Historycznym, jak we Wrocławiu, czy wśród socjologów i filozofów na Wydziale Filozoficznym na UJ. Na dodatek nazwy nasze tam, gdzie pada termin pedagogika, kryją czy gubią to, że zawodowe studia przysposobienia pedagogicznego wcale tam nie są prowadzone. Czego nie wie nawet pani minister Kudrycka, wmawiając nam niedawno, że słabość szkół w Polsce wynika ze słabości przygotowania nauczycieli na wydziałach pedagogicznych uniwersytetów. Pedagog szkolny z kolei wiadomo jak wąsko się kojarzy fikcyjnemu ciału pedagogicznemu naszych rad nauczycielskich, także fałszywie zwanych pedagogicznymi.

\section{Problem szukania alternatywy czy zmiany głównego nurtu?}

Wymaga uściślenia perspektywa traktowania pedagogiki krytycznej czy radykalnej, bo nie chodzi o to, aby była "tylko" alternatywna, czy tak nazywana i traktowana, jako odstępstwo od normy, czy zbuntowany margines. Znakomity Wydawca Oficyna Wydawnicza "Impuls” reklamuje naszą z Giroux książkę Edukacja i sfera publiczna jako reprezentanta pedagogiki alternatywnej i nie wiem, czy tym nie robi sprawie krzywdy, bo wpisuje w jakieś getto czy jakąś szufladę. Chodzi tymczasem o przebudowę głównego nurtu, jako ułomnego i ułudy. Ani pedagogika alternatywna, ani tym bardziej pedagogika krytyczna nie może być jeszcze jedną szufladą w wygodnym dla nas podziale pracy i wycinaniu sobie kółek zainteresowań. Pedagogika krytyczna to jest paradygmat dla całej pedagogiki, odwracający relację z tym, co jeszcze Kotarbiński nazwał „fuszerowaniem dyscyplin” 
$\mathrm{w}$ ramach rzekomych specjalizacji. Kiedy pedagodzy radykalni sięgają po gender studies to nie po to, aby uprawiać jakąś grządkę, ale by zapytać, co z nich wynika dla całej pedagogiki, jeśli ta nie chce być pod tym względem zapóźniona. Nie chodzi bowiem o jeszcze jeden typ pedagogiki zwany 'genderowym', ale o pedagogikę genderu jako przedmiotu refleksji, z której mają następnie wynikać ważne podpowiedzi dla rozmaitych dyscyplin pedagogicznych, a dokładniej dla całej pedagogiki. Kiedy w pedagogice krytycznej pojawiły się nawiązania do postmodernizmu czy ponowoczesności, a w ostatnich książkach Giroux jest dużo odwołań do Baumana, to nie po to, aby stworzyć jeszcze jedną szufladę. Nigdy nie chodziło tu o tworzenie jakiejś specyficznej wizji, np. pedagogiki postmodernistycznej, ale o wskazanie, na co musi umieć się zdobyć pedagogika nowocześnie odniesiona do stanu, który od jakiegoś czasu wspomniany Zygmunt Bauman określa mianem płynnej nowoczesności, zamiast ponowoczesności.

W polskiej pedagogice mamy za sobą okres gdy rozmaici, także wybitni uczeni ogłaszali, że uprawiają pedagogikę „socjalistyczną” (Suchodolski, Mysłakowski, czy Muszyński) i uwikłali się na wiele sposobów w taką etykietę, z której, jak wiemy, dziś nie pozostało zupełnie nic. Tam, gdzie taka pedagogika była mądra i wartościowa, żadną miarą nie musi być wciśnięta w etykietę ",socjalizmu”, podobnie jak tam, gdzie była w tę etykietę wciśnięta, nie musiała wszędzie być dogmatyczna i głupia. Po prostu etykieta socjalistyczna była całkowicie irrelewantna, czyli od rzeczy.

Twierdzę, że z terminami takimi, jak pedagogika alternatywna, pedagogika emancypacyjna, pedagogika krytyczna jest, a nawet MUSI BYĆ tak samo. Z jednym uściśleniem: krytycyzm jest postulatem METATEORETYCZNYM. Uwikłanym w dwoistość $\mathrm{z}$ troską o ujęcie systemowe, związane z zapytaniem o uzasadnienie strategii krytycznej. Apeluje do poziomu zorganizowania siły dyskursu i do niezbędnego wobec niego dystansu. Krytyka może być bezkrytyczna wobec samej siebie. Nie o taki krytycyzm nam chodzi. Krytyka nie musi być tylko demaskatorska i to w żadnym z trzech sensów, które wskazałem w nawiązaniu do typów statusu maski. Bardziej pożądana jest pedagogika alarmistyczna, gdy alarm oznacza już zagrożenie zasadnicze, ze zdolnością jego uprzedniego zdiagnozowania. Demaskatorska jest krytyka zrywająca maskę. Alarmistyczna jest krytyka, że maski zdjąć się nie da, bo broni swoich roszczeń. Tymczasem największe zło nie pojawia się tylko w masce, ale w ostentacyjnie cynicznej minie, że i tak nikt nic mu nie zrobi. Domaganie się zredukowania uniwersytetów do rynku wcale nie wymaga demaskacji jako szkodliwe, bo ono jawnie ogłasza, że chodzi o zredukowanie uczelni do szkoleń, do oczekiwań pracodawców, a nie o wzniosłości kulturowe czy rozwój duchowy ludzi. Nie musi, a nawet nie może być "systemowa”, gdyż unieważnia to troskę o krytykę samego systemu (założeń, intencji, nadziei, wyczuleń).

Krytyka wobec edukacji może być sentymentalna i chybiona w swoim roszczeniu do czystości własnych intencji, ich szlachetności, a w istocie naiwności. Jak uniknąć naiwnej krytyki sentymentalizującej np. opór, czy ideologicznie manifes- 
tującej ślepo poczucie wyższości? To ważne pytanie dla pedagogiki krytycznej. Jeden z trudno przebijających się w naszej świadomości kierunków odpowiedzi brzmi, jak to pokazuję rekonstruując historię pedagogiki na tle stanu nauk społecznych, w tym socjologii jak u Simmla, Eliasa czy Baumana, że musi być świadoma wymagań paradygmatu dwoistości, uczulającego np. na wspomnianą już groźbę, że może być kiczowata krytyka kiczu, albo z drugiej strony nierozumna pochwała rozumu. Krytyka wobec szkoły sama wymaga czujności krytycznej, krytycyzm nie jest immunizowany na wymogi czujności w sprawie pozycji, z których przemawia i widzi świat, czy choćby tylko jego część edukacyjną. Demokracja wyzwoliła się już z absolutyzmu i automatyzmu rachunkowego, opartego na racji większości, a uciążliwe celebrowanie różnicy stało się znamieniem kultury demokratycznego współbycia jako współżycia, przynajmniej tam, gdzie mamy do czynienia z dojrzałością sfery publicznej czy odpowiedzialnością polityczną, zamiast ogłaszania, że zwycięzca bierze wszystko, a opozycja ma w zamian swoje „zbójeckie prawo" stosowania wszelkich chwytów.

Warto też pamiętać, że krytyka nie ma oznaczać jedynie jakiejś alternatywy czy alternatywności w stosunku do także jakoś prawomocnej pedagogiki pozbawionej krytycyzmu. Kiedy Bogusław Śliwerski odkrywał dla nas antypedagogikę i była wspólnie prezentowana w tomie o pedagogice krytycznej we współredakcji z młodym jeszcze Tomaszem Szkudlarkiem (mając już kilkanaście co najmniej wznowień), to myśmy już jednak wiedzieli, że trzeba poszukiwać czegoś zupełnie innego, bo nie wystarczy deklaracja: nie będę Cię wychowywat ani nie chcę sprawować władzy, aby relacje podporządkowania zniknęły. Styk pedagogiki krytycznej i antypedagogiki okazał się nad wyraz złudny, mimo że w obu przypadkach o jakiś krytycyzm chodzi. Pedagodzy radykalni szukali krytycznej psychologii i powstawały teksty Phila Wexlera o „psychologii krytycznej”, gdy jednocześnie byliśmy czasem przekonywani, że antypedagogika nie potrzebuje żadnej psychologii, bo przecież nie potrzebuje psychologii ... oddziaływania czy wpływu, gdy nie chce oddziaływać ani ustanawiać relacji dominacji. Tak, jak gdyby zawieszenie intencji sprawowania władzy samo automatycznie znosiło relację władzy. Okazało się więc w sumie dość niefortunne, że poza "nieobecnymi dyskursami” pierwsze skojarzenia dotyczące pedagogiki krytycznej były z krzywdą dla niej jednorodnie sprzęgające ją z antypedagogiką. Żałuję, że o tej sprawie nie możemy bliżej i na serio porozmawiać wobec nieobecności Bogusława Śliwerskiego. Wypada zauważyć jedynie, że wśród 18 „współczesnych teorii i nurtów wychowania” w ważnych i godnych uznania rozważaniach Bogusława Śliwerskiego ${ }^{7}$ są finezyjne odróżnienia i podziały na pedagogikę nieautorytarną czy antyautorytarną, radykalnego humanizmu Fromma czy emancypacyjną Freirego, a krytyczna nauka o wychowaniu wiąże się z Habermasem, Girouxa nie ma, a Freire wpisany jest $\mathrm{w}$ ujęcie, z którym ja bym dyskutował. Ale to na inną okazję. Kwestie te są jednak kluczowe dla naszej kultury pedagogicznej.

7 Por. Wspótczesne teorie i nurty wychowania, Oficyna Wydawnicza „Impuls”, Kraków 1998. 
Jak już, to od lat 80 . wolałem włoską wersję pedagogiki krytycznej w postaci clinica della formazione Riccardo Massy, gdzie podejście 'kliniczne' było uściśleniem jego rozumienia krytycyzmu pod wpływem bezpośredniego otwarcia na trop Michela Foucault, z jego władzo-wiedzą i na "szkołę frankfurcką”, a myśmy zaczęli wówczas samodzielnie czytać Habermasa, gdy panowie z NRD z Greiswaldu mówili nam, że oni z Habermasem "rozprawili się" już dawno. Tymczasem zauważmy, że niepodjęcie u nas głębszych analiz na temat tego, co niesie "dyskurs kliniczny" dla pedagogiki (jako wzór i jako zaplecze specyficznej wiedzy), jest dodatkowo świadectwem naszej ułomności wpisywania się środowiska we własną tradycję, gdyż zarówno Stefan Wołoszyn jak Wincenty Okoń dawno postulowali nawiązanie przez pedagogikę ściślejszej relacji z podejściem $\mathrm{w}$ medycynie, zwłaszcza w zakresie badań nad patologią. Pełniejszy styk z podejściem klinicznym ułatwiłby także nasycanie pedagogiki wątkami z psychoanalizy, zagłuszonej dotąd $\mathrm{w}$ pedagogice jej ograniczeniem $\mathrm{w}$ dyskursie akademickiej psychologii.

\section{Problem odniesienia do krytyki w kontekście pedagogiki porównawczej}

Zająć się warto pytaniem o to, czy jest miejsce na pedagogikę krytyczną w opisach i typologiach stanowisk pedagogicznych, jakie spotykamy w naszej literaturze. Dotąd moim zdaniem nie ma i to nie tylko dlatego, że pedagogika krytyczna została wyłączona do klasy „nieobecne dyskursy”. Albo dokonuje się rozmaitych typologii, do odrębnych kategorii wpisujących Freirego, Habermasa z jednej strony i przeciwstawiających sobie rzekomo istniejącą pedagogikę emancypacyjną oraz pedagogikę wyzwolenia, albo pedagogikę postmodernistyczną. Wszystkie te próby uznaję za nieuprawnione i teoretycznie nieciekawe. Od Habermasa znamy pułapkę dla interpretatorów, polegającą na tym, że z jednej strony jest wyróżniony u niego "interes emancypacyjny”, ale z drugiej strony mamy residua emancypacji dzięki każdemu z pozostałych interesów poznawczych i residua te są obecne w każdym typie racjonalności. Także racjonalność „instrumentalna” (uprzedmiotawiająca, oparta na mechanizmie panowania i podporządkowania) ma oczywiście swoje residuum emancypacji (od ograniczeń natury przyrodniczej), tak jak racjonalność konsensualna ma swoje residuum emancypacji od ograniczeń społecznych w zakresie nieporozumienia się.

Tak jak słowa wolność czy rozwój nie należą tylko do dyskursu liberalnego, tak i słowo tradycja, autorytet czy kanon nie należą jedynie do dyskursu konserwatywnego. Istnieje liberalna afirmacja tradycji, jak i konserwatywna wizja wolności. Potrzebny jest słownik pedagogiki krytycznej, który ma swoją specyfikę kategorii, jak: upełnomocnienie albo postawa "transformatywnego intelektualisty", czy zadanie dekonstrukcji kanonów, a z drugiej strony specyficzne znaczenie kategorii tradycyjnych $\mathrm{w}$ pedagogice, jak chociażby autorytet, co pokazałem $\mathrm{w}$ tomie I o wyzwaniach autorytetu w Impulsie. 
Kluczowa jest kwestia, jaki projekt normatywny wiąże się z tym samym terminem. Pedagogika krytyczna nie musi wyrzucać na śmieci autorytetu ani kanonu, w drugiej sprawie Giroux mówi o potrzebie jego dekonstruowania, zaś w pierwszej o wartości autorytetu emancypacyjnego związanego z postawą transformatywnego intelektualisty, postuluje tożsamość pogranicza albo tożsamość hybrydalną, zwraca uwagę na kategorię głosu, jako głębiej sięgającą w praktykę edukacji i społeczeństwa niż sama afirmacja podmiotowości. Pozwala bowiem zadawać konkretne pytania i stosować surowe kryterium w zakresie tego, kto ma prawo głosu, kogo do głosu się dopuszcza, czyj głos jest słyszalny i czyj głos może być wysłuchany.

\section{Krytycyzm pedagogiki w warunkach polskich}

Podejmijmy wreszcie trzeci blok zagadnień, jaki zamierzyłem. Jeśli nie ma jednej pedagogiki krytycznej, a pedagogika jako taka, jeśli istnieje, musi być krytyczna, to jak to rozumieć w kontekście polskim i to obecnym? W Ameryce mamy za sprawą tytułów ostatnich książek Girouxa wskazanie na 'terror liberalizmu', walkę o odzyskanie uniwersytetu zakuwanego w łańcuchy kompleksu militarnego, czy patologie masowej kultury w wydaniu nawet Myszki Miki, z miękkim wdrukowywaniem nastawień przejmowanych w konwencji zabawowej i pozornie niewinnej.

U nas nie wystarczy już kojarzenie krytycyzmu z funkcją demaskatorską, niezbędny jest dyskurs nazwany przez Z. Kwiecińskiego dyskursem alarmistycznym, czy wysiłek odsłaniania inspiracji pedagogicznych z dyskursu dyskretnego. Walka o uniwersytet musi się wiązać zarówno z odzyskiwaniem funkcji kulturowej edukacji wyższej przeciw powracającemu szczytowi patologii nakazujących tylko taką edukację, która przyda się zawodowo na rynku pracy. To zbiorowe szaleństwo powraca co jakiś czas, już Hegel je wyśmiewał w czasach jego uniwersytetu, oskarżając część środowiska profesorskiego, jako ulegającego temu szaleństwu. Stąd teza, pedagogika jeśli jest, jest krytyczna także w sensie rozpoznawania zbiorowego szaleństwa, jakiemu dla własnej wygody i z dominującej głupoty jesteśmy w stanie ulegać.

Mało uczestniczymy w debacie publicznej, podczas gdy Giroux uważa to za istotny aspekt niezbędnego funkcjonowania krytycznego intelektualisty. U nas do wyjątków i niezwykłego wydarzenia urastają indywidualne wywiady w gazetach czy tygodnikach, jak niedawno znakomity Tomasza Szkudlarka, czy w innej konwencji i perspektywie aksjologicznej Aleksandra Nalaskowskiego. Sam nie bardzo to umiem i lubię, mimo że kilka prób w "Gazecie Wyborczej” i w jej dodatku lokalnym poczyniłem, wcześniej nawet próbując sił w felietonach krytycznych w trzech kolejnych odsłonach gazetowych. Co gorsza jednak, nie czytamy wzajemnie swoich książek, nie odtwarzamy najcenniejszych tropów z historii myśli pedagogicznej, zaczynając od „Chowanny” Trentowskiego, pozostawionej przez 
nas bez widocznego sensu i pożytku samym historykom wychowania, a która jest kopalnią idei pedagogicznych, także oczywiście błędnych, ale warta bardziej czytania niż niejedna współczesna pozycja koryfeuszy dyscyplinarnych, w tym podręczniki, bywa przedwczesne, albo wręcz niewczesne, chybione jako niewpisujące się $\mathrm{w}$ dorobek tradycji.

Grozi nam katastrofa intelektualna w środowisku, jeśli pedagogika polska nie stanie się naprawdę pedagogiką, czyli dyskursem krytycznym, zarazem dojrzale samokrytycznym. Jednocześnie musimy ten krytycyzm traktować jako zadany, a nie dany, kroczący i rozwijający się, przemieszczający, a nie dający się skodyfikować ostatecznie. Krytyka jest zawsze lokalna, historycznie i przestrzennie, będąc zakładnikiem swojego czasu i swoich ograniczeń, które da się zobaczyć jedynie z oddali. Jednym z zadań, które uświadomione i podjęte zmieniłyby kondycję dyscypliny, jest zadanie krytycznego odniesienia się do dorobku pedagogiki z czasów PRL, w jej najbardziej potocznie afirmowanych wariantach, nie wyłączając twórczości Bogdana Suchodolskiego. Pierwsze kroki w tę stronę staram się zrealizować w najnowszej swojej książce .

Wskazanie na kierunki troski o upełnomocnienie obywatelskie musi iść u nas w parze z troską o funkcję kulturową, przeciw wykorzenieniu z dziedzictwa symbolicznego, które nie musi być rozumiane konserwatywnie, ale jako gleba rozwijającej nas dziejowości, jak nazwał to Heidegger w swojej sztandarowej książce Bycie i czas.

Nie umiemy często czytać tradycji krytycznej ani jej wykorzystywać w naszym pisaniu. W jednym z niedawnych podręczników z pedagogiki ogólnej Bourdieu jest jedynie wielokrotnie przywołany. Jako afirmujący rzekomo mamy prawo do automatycznego czucia się wręcz "depozytariuszami” naszych dyscyplin. No to ja wolę lekturę Bourdieu, stanowiącą trzon niezbędny dla poważniej traktowanej pedagogiki ogólnej, z odniesieniem do takich kategorii jak: rytualizacja pozoru, ekonomia oszustwa, zysk symboliczny, postawa sojuszników w złej sprawie (adversaires complices), pary epistemologiczne, etc. Potrzebujemy pojęć krytycznych, by móc pojmować, by pojąć, czyli pochwycić krytycznie. Rozumienie staje się kategorią bardziej ofensywną także politycznie i kulturowo; jak uczulał na to Adorno9 ${ }^{9}$ również uprawianie filozofii i nauki może być barbarzyń- stwem, jeżeli z oglądu stanu rzeczy nie wynika postulat jego zmiany, zamiast sankcjonowania status quo czy samego podejścia do zmiany.

\footnotetext{
8 Por. L. Witkowski, Przetom dwoistości w pedagogice polskiej między historia i teoria, Oficyna Wydawnicza „Impuls”, Kraków 2012.

9 Por. T.W. Adorno, Minima moralia. Refleksje z poharatanego życia, Wydawnictwo Literackie, Kraków 1999)
} 


\section{Zamiast zakończenia: o naturalizacji świata jako źródle zagrożeń}

Zauważmy na marginesie, że to aż zagrożenia opisane przez Norberta Eliasa ${ }^{10}$ musieli mieć na myśli Frankfurtczycy w osobach Adorno i Horkheimera, gdy ostrzegali w Dialektyce oświecenia ${ }^{11}$, że postawa ćwierćinteligentów i półinteligentów jest groźniejsza dla kultury od postaw analfabetów, gdyż ci ostatni nie aspirują do pozorowania zachowań np. elit intelektualnych, podczas gdy ci pierwsi prowadzą do "niwelacji” różnic i wyrównywania standardów, ale za cenę w istocie ciągnięcia ich w dól. Kategoria niwelacji wielokrotnie powraca u Eliasa i warto ją wykorzystać do kojarzenia tu powiązania niwelowania różnic za cenę degradacji sposobów przejawiania się modeli w trybie rytualizacji ich pozoru. Za mało mamy najwidoczniej świadomości zagrożeń, jakie dla kultury niesie dopuszczanie zdegradowanych form pozornego awansowania do warstw „wykształconych" poprzez umasowienie fikcyjnej jakości edukacji, zwłaszcza na poziomie nominalnie wyższym. Podkreślmy w ramach tej ważnej dla nas tu dygresji, że te same (czy analogiczne) zjawiska warto by dostrzegać i obnażać w obszarze mechanizmów komponowania uczestnictwa w życiu i emanacji środowisk akademickich, z udziałem osób, które nigdy dość wysiłku do sprostania wymogom najwyższych standardów nie podjęły, ale którym to nie przeszkadza jednocześnie aspirować do wyróżników statusowych, nie wyłączając sprawowania władzy akademickiej i pozornego bycia „depozytariuszami” tradycji poszczególnych dyscyplin, z racji zdominowania ich swoją pozycją instytucjonalnego hegemona.

Jednym z zadań, jakich nie umiemy problematyzować nadal w praktyce relacji w obrębie zróżnicowania w kulturze, jest samo przekładanie na wartość i potencjał spotkania z różnicą. Tolerancja bardzo często kojarzy się z lekceważeniem z jednej strony, a roszczeniem do nienaruszalności, z drugiej. Powstają rozmaite przejawy getta i gettoizacji zabijające możliwość oddziaływania wzajemnego i traktowania różnicy jako bogactwa, którym da się ożywić i ożywiać relacje. Zauważmy, że słusznie i znakomicie Mirosława Dziemianowicz pokazywała, że edukacja zróżnicowana (separacji płci) de facto niszczy wartość płci dla siebie w ich funkcji generowania ważnego doświadczenia także kulturowego i okazji do nabywania kompetencji w zakresie zdolności do upominania się o siebie w przestrzeni interakcji, a nie rozdzielenia. A tak ta Orwellowsko nazwana edukacja, niszcząca wartość różnicy poprzez jej sztywne podtrzymywanie w gettach, uruchamia procesy stereotypizacji socjalizacyjnej już nie tylko w zakresie płci, zawodów, postaw w sferze publicznej, ale i rekrutacji do samej obecności i zabierania głosu. Na fali zainteresowania zjawiskiem interdyscyplinarności widać, jak bar-

10 Por. N. Elias, Przemiany obyczajów w cywilizacji Zachodu, Państwowy Instytut Wydawniczy, Warszawa 1980.

11 M. Horkheimer., T. Adorno, Dialektyka oświecenia, Wydawnictwo IFiS PAN, Warszawa 1994. 
dzo pozamykane od wewnątrz specjalności same na tym zamknięciu tracą, uwikłane w iluzoryczne jakości służące do fuszerowania całych dyscyplin na lata, a nawet pokolenia. Mam dowody na to, że pedagogika znalazła się w takiej sytuacji, jeśli porównać jej potencjał międzywojenny z dominującymi trendami w PRL, na co remedium jest możliwe moim zdaniem jedynie przy zaangażowaniu impulsów w trybie zwielokrotnionego i transwersalnego krytycyzmu.

Reasumując: pedagogika krytyczna w jej rozmaitych przejawach pokazuje minimum radykalizacji dyskursu i dążeń, akademickich czy obywatelskich, które pora intensywniej wykorzystywać. Jest wyzwaniem do podjęcia pod groźbą tego, że zadowoleni $\mathrm{z}$ siebie i zadomowieni $\mathrm{w}$ swoich gettach dyscyplinarnych nawet nie dostrzeżemy momentu, w którym marzenie o demaskatorskiej funkcji będzie niemożliwe do realizacji nie dlatego, że nam ktoś w tym będzie przeszkadzał, ale dlatego, że sami swoją ślepotą, niemotą i głuchotą, jednym słowem: głupotą, nie będziemy $\mathrm{w}$ stanie sprostać zadaniu przebudzenia, a następnie przetarcia oczu i podjęcia czynności codziennych z myślą o przyszłości. Pozostanie biadolenie nad naszym losem, który sami sobie zgotujemy. A nawet pewnie jest już prawie gotowy, z małymi szansami na jego odwrócenie. Tymczasem można nawet zupę tak robić, że nie da się jej zjeść, mimo że będzie z torebki z napisem „Smaczna”. Pozostaje życzyć smacznego!

Teza kluczowa z wyżej powiedzianego jest jedna: nie ma już alibi na nieobecność impulsów krytycznych dla pedagogiki w samokształceniu, dydaktyce i badaniach w Polsce i to niekoniecznie impulsów pochodzących z samej już intencjonalnej pedagogiki krytycznej w codzienności naszego funkcjonowania akademickiego. Impulsy krytyczne pojawiają się w różnych typach dyskursu, które przedstawił Zbigniew Kwieciński, a zilustrowała ich działanie wykorzystując konteksty kulturowe Monika Jaworska-Witkowska w ich niedawnej wspólnej, niezwykłej książce ${ }^{12}$. Chodzi tu w szczególności o rozmaite praktyki dyskursywne oraz rozmaite postaci intencjonalności pedagogicznej, przynoszące efekty, z których trzeba umieć odsłonić inspiracje krytyczne dla pedagogiki z literatury i innych obszarów kultury oraz $\mathrm{z}$ różnych dyscyplin $\mathrm{w}$ integralnie pojmowanej humanistyce. Mamy całe mnóstwo niedocenianych i przez to niewykorzystanych w pedagogice nowych tropów kulturowych i humanistycznych, jakie przebiły się, także dzięki przekładom w Polsce, w obszary przyległe do pedagogiki, przez co nie ma już alibi na zamykanie naszego dyskursu w kanonie czy konwencji znanej naszym starszym kolegom czy ich młodszym ofiarom, skazanym, ale i skazującym się brakiem szerszego oczytania na zbyt już ograniczony kontekst dla prac pisanych na stopnie. Badacze w naukach społecznych mogą sobie funkcjonować zamknięci w swoich algorytmach, schematach, parametrach, statystykach. Pedagog nie może takiej postawy powielać, jeśli ma go być stać na głębsze funkcjono-

12 Z. Kwieciński, M. Jaworska-Witkowska, Nurty pedagogii: naukowe, dyskretne, odlotowe (Oficyna Wydawnicza „Impuls”, Kraków 2011. 
wania, jako że to świadomość i czujność humanistyczna tu jest kluczowa, a nie same intencje i sztywność procedur.

W przeciwieństwie do tezy Suchodolskiego z końca lat 80., że pedagogika nie ma już do czego się odwołać ani na czym oprzeć, jest wiele tropów, na których możemy dalej budować siłę i przenikliwość krytyczną dyskursu pedagogicznego, wykorzystując także tropy śmiało nawiązujące do akcentów okrzyczanych mianem postmodernistycznych, choć najczęściej rozumianych na opak, szkodliwie dla zadania odnawiania nowoczesności. Nie ma jednego kanonicznego nazwiska, kręgu, ani jednej obowiązującej wykładni. Trzeba umieć składać potencjał krytyczny z nanizywania, jak w przypadku sznura korali, idei jak pereł myślowych, dając sobie możliwość rozpoczęcia "gry szklanych paciorków”, o której pisał znakomity noblista z 1946 roku Hermann Hesse w tomie pod tym tytułem.

Wówczas odkryjemy także kategorię „oświeconego cynizmu” za Peterem Sloterdijkiem, orwellizację mowy, terror przeciętności skażonej syndromem masowości, etc. Nie ulega moim zdaniem wątpliwości, że cynizm uczestników życia publicznego i reprezentantów jego oficjalnych instytucji, nie wyłączając instytucji edukacyjnych i politycznych, oraz orwellizacja języka to istotne wyzwania dla demokracji, z punktu widzenia troski o społeczeństwo obywatelskie. To jest obszar szczególnie ważny nie tylko dla pedagogiki społecznej w Polsce, wymagający podejścia wpisanego w tradycję krytyczną. W postawie krytycznej trzeba wiedzieć, przeciw czemu się jest i jaką ma wartość alternatywa, w tym - czy krytyka sama wytrzymuje krytykę, a jakiej nie wytrzymuje. Zastanowienie się nad tym, co może być przedmiotem krytyki, jest pośrednio sposobem analizy tego, gdzie są ustanowione bariery komunikacyjne i presje władcze wyłączające spod refleksji chroniącej przed degeneracją. Na dodatek niebezpieczne i godne krytyki są nie tylko zachowania skrajnie ofensywne, ostentacyjne czy agresywne, ale zamaskowane, uprzejme, dające poczucie afirmacji podmiotowości, naturalizując pewne stany jako iluzorycznie nie do zmiany, nawet niewidoczne w ich przezroczystości.

Pozostaje, jako ważne do podjęcia, zasadnicze pytanie o to, czy jesteśmy w swoim podejściu poznawczym i etycznym wystarczająco radykalni w sensie docierania do korzeni zjawisk, czujni na rozmaite wykładnie sensu i wartości, a tym bardziej gotowi do wysiłku źródłowego konfrontowania tego, co dociera do nas jedynie w opakowaniu autorytatywnych redukcji. Zmienia się charakterystyka potencjalnego przedmiotu wymagającego czujności i uważności radykalizującej nasz potencjał upominania się o siebie. Oswojenie i naturalizacja (roszczenie do bezrefleksyjnej oczywistości urządzenia świata społecznego) to główne źródło zagrożeń. Przedmiot wymagający krytyki nie tyle sam się zakamuflował albo obudował niedostępnością jakiegoś zewnętrznego obwarowania, ile wbudował to obwarowanie w nas samych poprzez to, że się naturalizował w naszych oczach: bezalternatywnością, polityczną poprawnością, inercją proceduralności, uprzejmością i zdolnością nadużywania mechanizmów i praktyk demokratycznych, np. wyborów, brakiem autentycznej wspólnoty akademickiej ludzi rozmawiających ze sobą i spierających się o ważne próby badawcze i publi- 
kacje. Większość pozamykała się w swoich gettach i mozolnie ciuła punkty oraz publikacje na stopień taki czy owaki.

Nie sztuka krytykować totalitaryzm czy autorytaryzm. Sztuka zobaczyć zakamuflowane zapędy do miękkiej przemocy ukrytej, a tym bardziej takie, które działają na poziomie socjalizacji, wymagając desocjalizacyjnej czujności, dla wyrywania jednostek i grup społecznych z tego wiru redukcji kulturowej. Proszę mi pokazać podręcznik pedagogiczny, który o socjalizacji także tej pożądanej mówi w kategoriach perwersji i perfidii oddziaływań nawet szczytnych. A jest to niezbędne, bo socjalizacja sankcjonuje to, co SIĘ robi, zarazem udając, że to wzory osobowe, a poza tym zaciera po sobie ślady, bo człowiek nie wie już wtedy, czego go to pozbawiło, wdrażając go w świat udawanej oczywistości, gdzie indziej nie kryjącej swych arbitralnych roszczeń. Niezbędne jest widzenie funkcji edukacji, mimo ciągłego jej uwikłania w socjalizację, jako stawiającej zadanie desocjalizacji, rozbijania zastygających struktur zwalniających z myślenia, z dopuszczania do głosu różnicy jako życiodajnego impulsu. Ważnym aspektem krytyczności pedagogiki jako całości dyskursu i praktyki jest uznanie wreszcie wszędzie OBOSIECZNOŚCI środków, jakimi się musimy posługiwać, DWOISTOŚCI sytuacji działania, skazującej nas na napięcia i nieredukowalne dylematy, ciągle grożące jednostronnością wyborów. Oznacza to wpisanie naszego działania w perspektywę dwubiegunowości, od której nie jest wolny żaden przejaw naszych dążeń pedagogicznych, jak to pokazuję w najnowszej książce ${ }^{13}$.

Dodam, już na samo zakończenie, choć nie gwoli jedynie kurtuazji, ale z wewnętrznej potrzeby, że Uniwersytet Gdański i jego środowisko pedagogiczne jest jak najwłaściwszym miejscem na debatę o kondycji i zadaniach pedagogiki krytycznej w Polsce. Dzięki wczesnemu kontaktowi z analizami Giroux stało się ono, zwłaszcza za sprawą rozwoju i oddziaływań twórczych Tomasza Szkudlarka, wiodącym ośrodkiem w kraju, promieniującym nową optyką badań i narracji pedagogicznej w zakresie krytyczności analiz i nowych wątków badań i teorii, obejmując między innymi krytykę neoliberalizmu (Joanna Rutkowiak), otwarcie na gender studies (Lucyna Kopciewicz), włączenia do analiz pedagogicznych tradycji socjologii krytycznej, np. Bourdieu i Foucault (Astrid Męczkowska). Rosną także młodzi badacze. Dzięki między innymi środowisku pedagogicznemu Gdańska po impulsach teorii krytycznej nastąpiło moim zdaniem w kraju - mimo że z oporami i w ograniczonej skali - przesilenie pokoleniowe, a w samym tym ośrodku powstaje wręcz nowa szkoła badań pedagogicznych, której obecność można znakomicie uwypuklić przy okazji organizacji przyszłorocznego Zjazdu Pedagogicznego, którego gospodarzem znów będzie Gdańsk. Można by też pokusić się o jakąś formę uhonorowania na nim samego Girouxa, dla podkreślenia wagi ewolucji badawczej wokół strategii krytycznej w pedagogice, jaka się dokonuje w ciągu ostatniego ćwierćwiecza. Skala wpływu twórczości Henry’ego Girouxa

13 Por. L. Witkowski, Przełom dwoistości w pedagogice polskiej, między historią i teoria, Oficyna Wydawnicza „Impuls”, Kraków 2012). 
na zmiany, nie tylko w pedagogice gdańskiej i jej strategii dydak- tycznej, kierunków badań i dokonań indywidualnych, w tym rozwoju naukowego nowego pokolenia badaczy (z Tomaszem Szkudlarkiem na czele), jest nie do zlekceważenia i zasługuje na szersze uznanie. Cieszy fakt, że nowe i dynamiczne pismo pedagogiczne, jakim jest Ars Educandi, siłami jego młodego, przebojowego i twórczego trzonu redakcyjnego sprzyja refleksji nad tym nurtem, a może i z czasem przyniesie istotny refleks w kondycji kolejnego pokolenia młodych pedagogów i jego uwrażliwień badawczych oraz zaangażowania obywatelskiego i kulturowego, tak bliskiego radykalnemu rozumieniu misji edukacji we współczesnym świecie. Tego należałoby sobie życzyć.

\section{Summary}

Around critical pedagogy (retrospection and projection at the background of problems and experiences in polish pedagogy)

The content of the article is the status of radical and critical theory of education in Poland. The Author presents the educational theorists' generational experience that included both the initial contact with radical and critical pedagogy as well as following attempts to find strategies explaining the reality of the transformation period. The text is therefore an attempt to answer the question about the ways of practicing critical pedagogy in Poland but also about the foundations of criticism and crititicality in general. 